\title{
MODERN MEDICAL YOGA: STRUGGLING WITH A HISTORY OF MAGIC, ALCHEMY AND SEX
}

\author{
Joseph S. Alter
}

\begin{abstract}
The history of modern yoga is rooted in the history of alchemy and the practice of magic in medieval India.' In physiological terms it is also intimately linked to tantric ideas concerning the immobilisation of semen. However, modern yoga as a form of practice which emphasises physical fitness, wellness and holistic health, emerged more directly out of the early twentieth-century yoga renaissance. Leading figures such as Shri Yogendra and Swami Kuvalyananda sought to purge yoga practices such as asana, kriya and pranayama of all things esoteric, mystical and magical and establish practice on the basis of pragmatic, rational, scientific principles. They did this within a framework of what can be called secularised spiritualism. Since the early part of the last century yoga has been popularised, systematised and routinised on these terms, as reflected in countless schools founded by teachers with various degrees of training and experience, as well as in thousands of popular, scientific and academic publications. In all of these schools and publications - both more and less spiritual and philosophical - there is, it will be argued, a degree of profound ambivalence if not explicit contradiction between a secularised, 'sanitised' scientific ideal of medicalised practice, and the 'other history' of sex, magic, and alchemy. This 'other history' both undermines and authorises the idea of yoga as medicine, and, it will be argued, the tension between pragmatic rationalism and esoteric magic makes yoga powerful.
\end{abstract}

\section{Epigraph}

Even the most intellectually sophisticated schools of Yoga contain elements of magic or occultism. One may be tempted to view these features as simply being dysfunctional remnants of an earlier, uninformed age. However, any attempt to demythologize Yoga is doomed to failure, because it would involve the obliteration of vital aspects of this ancient tradition. ${ }^{2}$

1 'Medieval India', i.e. tenth and eleventh-century India.

${ }^{2}$ Feuerstein 1990, p. 243. 


\section{Introduction: history as context}

Given that yoga is now being subject to clinical trials in many different parts of the world, it would be redundant to point out that yoga has been completely medicalised. Clearly the contemporary practice of yoga can entail other things that are more philosophical and spiritual - if no less physical - but in many ways the popularity of yoga manifest in the popular practice of asana (postural exercises) and pranayama (breathing exercises) is directly linked to very modern ideas about holistic health and wellness. Yoga as a systematised form of physical fitness training on the one hand and as applied medical therapy on the other unambiguously came into being in the early years of the twentieth century. As such yoga is a modern phenomenon. It may be going too far to say-but I will say it anyway to emphasise my point - that yoga as we know it today was invented, separately but at about the same time, by two men living in the Bombay Presidency. These two men set up modern medical clinics, theorised yoga in terms of rational, scientific principles and conducted numerous laboratory experiments to prove the efficacy of asana, kriya (i.e. purification techniques) and pranayama, as well as pratyahara (withdrawal of the senses), dhyana (meditation), dharana (concentration) and samadhi (embodied enlightenment). They took on names that self-consciously evoke a very different kind of yoga and a different history of yoga's development. In the early 1920s Manibhai Haribhai Desai became Shri Yogendra and established, in Bombay, the first yoga hospital. At about the same time a young nationalist revolutionary from Baroda named J.G. Gune became Swami Kuvalyananda and established the first research institute for the scientific study of yoga in Lonavala, near Pune.

In this article I wish to make two interrelated points. First, that modern yoga is just that-modern and thereby informed by and structured in relation to twentieth-century ideas about health, fitness and disease. Secondly, that the power attributed to yoga as medicine and as a regimen of public health is intimately linked to tenth and eleventh-century ideas about sex, magic and alchemy, even though these ideas have, for the most part, been systematically and self-consciously purged from the discourse and practice of yoga.

As Kenneth Zysk has pointed out, it is possible and very enlightening to trace the development of ideas about prana as vital breath in the history of Indian medicine and, as Kuriyama and others have 
shown, the principle of vital breath is directly relevant to the development of ideas about health well beyond South Asia. ${ }^{3}$ However, as Sjoman points out and as David White makes clear, it is very difficult to reconstruct the history of pranayama breathing exercises and asana practice between the tenth and the twentieth century. ${ }^{4}$ At least in part this is because prana (subtle breath) is a general descriptive term that is relevant to āyurveda, Samkhya philosophy and a range of other traditions, whereas pranayama is a specific set of techniques, and all techniques of yoga were conceived of as quintessentially secret, being imparted by a guru only to select highly adept disciples. ${ }^{5}$

As is very well known, but not always remembered, natha and kanphata yogis developed the practice of hatha yoga around the ninth or tenth century, ${ }^{6}$ and it was on the basis of this practice that the three primary hatha yoga texts were composed, the Hathayogapradipika around the mid-fifteenth century, the Gherandasamhita in the late seventeenth, and the Shivasamhita around the late seventeenth or early eighteenth centuries. $^{7}$ All three of these texts are very similar to one another, and they are all probably based on earlier works. ${ }^{8}$ There are numerous other texts that deal with the subtle body to various degrees, ranging from the early Upanishads (BCE 500-300), through the Jain and Buddhist texts, up to the critical period of the tantras and the final redaction of the Carakasamhita (2nd century CE), ${ }^{9}$ which have yet to be carefully studied and analysed comparatively. What is needed is something of the order of what Jan Meulenbeld has done

${ }^{3}$ Zysk 1993; Kuriyama 2002; Kawakita et al. 1995.

${ }^{4}$ Sjoman 1996; White 1996.

${ }^{5}$ For the most comprehensive analysis of Samkhya philosophy see Larson 1979; Larson and Bhattacharya 1987. McKim Marriott's ethnosociology (1990) is the most comprehensive and systematic discussion of the way in which Samkhya ontology and epistemology are integrated into a broad spectrum of historical processes and contemporary forms of day-to-day and ritual practice in South Asia.

${ }^{6}$ Briggs 1938; Eliade 1990, pp. 200-90; Singh 1937; White 1996. See also Buoy 1994; Lorenzen 1972.

7 The precise dates of these texts are far from certain. See Briggs 1938, pp. 251-7 and Feuerstein 2001, pp. 381-90, 400.

${ }^{8}$ Precise dates aside, Gorakh Nath is ascribed authorship of a range of different thirteenth-century texts entitled Goraksa Samhita. These contain clear references to hatha yoga techniques. The most comprehensive text attributed to Gorakh Nath, however, is the Goraksa Sataka, also written in the thirteenth century. See White 1996, p. 141.

${ }^{9}$ Feuerstein 2001. 
for ayyurveda. ${ }^{10}$ But it seems that all of extant hatha yoga literature tends to reiterate common themes. ${ }^{11}$

Without a clear and detailed historical record it is difficult to know how the most important concepts in hatha yoga developed and changed. Nevertheless there are several logical assumptions that can be made. First, given that all pre-nineteenth-century texts emphasise the importance of magical siddhi (lit. attainment, success) powers gained in the pursuit and embodiment of perfection through the practice of asana and pranayama, and given the very common cultural perceptionreinforced by the popular press and traveller reports in both the Mughal and British colonial period ${ }^{12}$ - that yogis possess supernatural powers, it is safe to assume that there was a close link between magic and yoga up until the late nineteenth century. Second, given the fact that hatha yoga, the physical form of yoga practice, developed in conjunction with siddha alchemy, ${ }^{13}$ and that many of the extant yoga texts make reference to alchemical principles, it is most probable that the idea of radical trans-substantiation was a consistent feature of practice up until the late nineteenth century. ${ }^{14}$ Finally, it seems quite clear that hatha yoga is historically linked to the development of tantric ideas, particularly with respect to ideas connected with kundalini. While kundalini yoga may be regarded as a distinct kind of yoga practice within hatha yoga, it seems clear that the under-

${ }^{10}$ Meulenbeld 2001.

11 Texts that may be specifically counted in the hatha yoga corpus are the roga Yajnavalkya, Ananda Samuccaya and the Carpata Shataka which all date between 1200 and $1300 \mathrm{CE}$. Important but not commonly known works that are attributed to Gorkshanath include Siddha Siddhanta Paddhati and Yoga Bija. Other works that deserve mention are the Brihad Yogi Yajnavalkya Smriti, Yoga Vishaya, Hatha Ratna Avali, Yoga Shastra, Yoga Karnika. See Feuerstein 2001, pp. 420-5.

${ }_{12}$ One of the first such reports is from Marco Polo's late thirteenth-century visit to the Malabar Coast (Needham 1980, pp. 497-8). David White provides a series of vignettes on the discourse of occultism and magic that characterises the travel literature - broadly defined - and documentary history from the fifth century up to the twentieth (White 1996, pp. 48-51). For the best sources on the colonial period see Oman 1903, 1908 and Crooke 1926).

${ }^{13}$ Siddha was a form of alchemy common in Southern Asia from the thirteenth through to the seventeenth century. It was based on the idea that the body could be perfected and rendered immortal through the consumption of mercurial elixirs.

${ }^{14}$ See White 1996, pp. 132-41. Of course, there is no need to assume that things changed abruptly as the nineteenth century gave way to the twentieth. As White points out (1996, pp. 335-52), the mystique - if not the practice of alchemy as such - of the Siddha legacy is clearly apparent in the contemporary practice of various kinds of ascetics, holy men and magicians. See also Siegel 1991. 
standing of the subtle physiology of nadi 'energy' conduits, which is axial to kundalini (the subtle power of enlightenment), is also fundamental to hatha yoga in general. Pranayama- whatever its effect on lung capacity and respiration-does not make sense except with reference to nadi physiology. Given the extent to which tantric principles inform the very logic of yogic physiology it is safe to assume that there was, at the very least, some sort of parallel development between the two up until the late nineteenth century. ${ }^{15}$ Very significantly there is an important link between siddha alchemy and tantric physiology in that both are conceptualised with reference to sex and sexual symbolism. ${ }^{16}$ The sexual-if by no means inherently erotic - nature of hatha yoga is, I think, also something that was characteristic of practice up until the nineteenth century. ${ }^{17}$

As Elizabeth De Michelis has pointed out, Swami Vivekananda must be credited with first articulating the parameters of modern yoga at the fin de siècle. ${ }^{18}$ Heavily influenced by nineteenth-century esotericism and by the romantic spiritualism of Rammohan Roy, Debendranath Tagore and Keshabchandra Sen, his seminal work, Raja Yoga (1896), combines a discourse of scientific rationalism with occultism to articulate, among many other things, a vitalistic Naturphilosophie focused on the agency of the guna (psychosomatic stands), prana, and akash (ether). ${ }^{19}$ Given his concern with spirituality and realisation, Vivekananda primarily focused on what might be called the more contemplative dimensions of yoga. Nevertheless, it is clear from what he wrote about pranayama that he regarded embodied experience-based on the flow of vital fluid energy - as very important. ${ }^{20}$ Thus he can be said to have initiated a broader concern

${ }^{15}$ In this regard it is relevant to point out that a number of the earliest texts that sought to demystify yoga were concerned with the esoteric physiology of kundalini. See, for example, Ewing 1901; Rele 1927; Roy 1930; Sivananda Sarasvati 1935a, 1935b; Wassan 1921, 1922 and in a somewhat different mode Woodroffe 1931.

${ }_{16}$ See, for example, Faure 1998; Padoux 1986; Rabe 2000; Sanderson 1988.

17 There is, in fact, a sub-genre within the voluminous self-help yoga literature that is directly, although covertly - and perhaps even unknowingly-linked to the pyro-erotics of tantric yoga. These manuals explain how yoga can be used to produce the 'non-duality of true love' that should characterise marital bliss, enhance sexual power, satisfaction and stamina, as well as allow for experimentation with different positions (See Neelam 1993, Sharma 1991).

${ }^{18}$ De Michelis 2004.

19 De Michelis 2004, pp. 153-68.

${ }^{20}$ De Michelis 2004, pp. 159-68. 
with embodied forms of practice, namely hatha yoga, kriya purification and breathing exercises. However, although clearly atuned to the subtle body, Vivekananda had very little to say about that which has come to define modern practice: asana.

Building on De Michelis's work, a richly rewarding historical research project would be to study developments in the practice of hatha yoga during the nineteenth century, perhaps starting as early as the mid-eighteenth. Given the rapid modernisation of hatha yoga around 1900, there must have been changes in the practice and thinking of adepts as they encountered - even indirectly-the institutions of modernity, or as they turned away from modernity to practise yoga in a mode that was self-consciously oriented away from the whole apparatus of Empire. How, for example, did the practice of hatha yoga factor into the promotion of physical fitness in Bengal and other parts of India between 1850 and 1900, as physical fitness was designed as the means by which to remasculate men rendered effete by modernity? ${ }^{21}$ When did good health and fitness become an end in itself, rather than a means to an end in the context of embodied transubstantiation? And - to extend the time frame ${ }^{22}$ back somewhat further - to what extent did so-called warrior ascetics practise hatha yoga to make themselves powerful ${ }^{23}$ Was this power conceptualised as physiological or was it, in some sense, supernatural? In this context is it correct to apply a direct and literal understanding of hatha yoga as forceful or violent yoga, as the etymology of the word hatha would suggest? ${ }^{24}$

${ }^{21}$ See Alter 1994, 2000; Rosselli 1980.

${ }^{22}$ Given that the two of the three primary texts in the hatha yoga corpus were composed as late as the seventeenth century, it would be particularly important to place an analysis of these texts in the context of late Mughal and early imperial history. Similarly an analysis of the Hatha Sanketa Candrika, an early eighteenthcentury text that contains detailed historical information, could shed important light on the practice of hatha yoga-and the practice of writing about yoga-at a critical point in time.

${ }^{23}$ See Farquhar 1925; Ghose 1930; Lorenzen 1978; Pinch 1996. In addressing this question it would be very important to keep in mind the 'classical' and medieval literature that attributes magical power and devotional strength to martial figures, in particular kings who acquire power through tapas (ascetic ardour) and various ascetic practices (Whitaker 2000). It would be a mistake to assume that there was a categorical break in the logic of power - from magical to mundane - in the putative shift from mythic to 'rational' configurations of thought.

${ }^{24}$ The etymology of the term hatha yoga provides the basis for endless interesting speculation. A number of scholars point out that the term hatha is a conjunc- 
Since my area of expertise, based on the methods of historical anthropology, is contemporary yoga, I am primarily concerned with the developments in yoga since the advent of modern, consumeroriented publishing. Although influenced by Vivekananda, ${ }^{25}$ it seems quite clear that what Kuvalyananda and Yogendra did in the 1920s, particularly with regard to asana, kriya and pranayama, was extremely innovative, if not completely without precedent. ${ }^{26}$ Before going into what it was that they did, however, let me briefly point out just how central the idea of magical power, alchemical transubstantiation and the immobilisation of semen is to what might be called the 'long stretch' of hatha yoga's early history.

\section{Magic, alchemy and semen virile}

In this day and age of post-colonialism and critical cultural studies Orientalists -irrespective of any occultist inclination-are much maligned. There is no denying that scholars of this ilk can be accused of many sins. ${ }^{27}$ Nevertheless, I would recommend that anyone interested in understanding hatha yoga as a historically and philosophically contextualised system of practice read, among many other things, the work of Sir John Woodroffe, Paul Deussen, Jean Varenne and, of course, Mircea Eliade. ${ }^{28}$ Based on three years of study with the

tion of the 'words'-actually phonemes - that designate the sun and the moon. Thus, hatha yoga can be said to mean the union of sun and moon on the level of the microcosmic body. Feuerstein 2001, p. 352. However, the word hatha unambiguously means forceful or violent effort, see Eliade 1990, pp. 228-9, and therefore signifies a kind of body cultivation that is, in many ways, the antithesis of what yoga has come to be associated with in the late twentieth century-relaxation, contemplative spirituality, holistic health and nonviolence.

${ }^{25}$ De Michelis 2004, pp. 182-3.

${ }^{26}$ Most significantly a complete and comprehensive study of Shri Krishnamacharya would help to provide a much clearer perspective on the modern history of hatha yoga. Krishnamacharya traced his lineage to the tenth-century Vaishnava bhakti saint Nathamuni and was the teacher of several of the most important exponents of modern hatha yoga: T.K.V. Desikachar, B.K.S. Iyengar, Indra Devi and Pattabhi Jois. As Sjoman points out, Krishnamacharya's yoga was probably very heavily influenced by the introduction of Western-style gymnastics into the Mysore palace in the late nineteenth and early twentieth centuries.

27 Taylor 2001; Urban 2003, pp. 106-203.

${ }^{28}$ Deussen 1906; Eliade 1990; Varenne 1973; Woodroffe 1927, 1929, 1931. Although not about yoga as such, in the context of this discussion it is worth drawing attention to Filliozat's Magie et Medecine 1949. 
famous Indian Orientalist Surendernath Dasgupta, Eliade's comprehensive study Yoga: Immortality and Freedom is a definitive modern classic. In The Alchemical Body, David White then picks up on and elaborates many of the points discussed by Eliade, demonstrating the historical, intellectual and philosophical connection between alchemy, tantrism, sexual physiology and hatha yoga. ${ }^{29}$

As Eliade points out, the yogis who 'invented' hatha yoga were concerned with what he calls 'the perfection of the body'. As reflected in the principle of kaya-sampat, perfection of the body came, significantly, from a conquest of the five material elements. Kaya-sampat was, therefore, conceived of in elemental, metabolic terms rather than in terms of 'physical fitness'. In this respect Eliade points out that tantrism and hatha yoga placed an extremely high value on the body and embodied experience.

[T] he will to master the body in order to transmute it into a divine body ... is especially the position of Hatha Yoga. Such mastery must begin modestly, on the basis of an accurate knowledge of the organs and their functions... But perfection is always the goal, and, as we shall soon see, it is neither athletic nor hygienic perfection. Hatha Yoga cannot and must not be confused with gymnastics. ${ }^{30}$

Eliade wrote this in the 1930s, based on research in the late 1920s, and I am certain that from the vantage point of the present he would have said that hatha yoga should not be confused with medicine either. Indexing āyurveda, he clearly points out that 'although the Hindus have elaborated a complex system of scientific medicine, nothing obliges us to believe that the theories of mystical physiology were developed in dependence upon this objective and utilitarian medicine or at least in connection with it'. ${ }^{31}$ In any case, it is important to

${ }^{29}$ White 1996.

${ }^{30}$ Eliade 1990, p. 228.

${ }^{31}$ Eliade 1990, p. 233. With respect to the empirical, rational and scientific nature of Âyurveda, Eliade is correct in making a sharp and unambiguous distinction between it and yoga. Clearly Âyurveda is based on a theory of natural laws, and is designed to explain the natural world and the functioning of the human body within it - and as part of it - with reference to the very real and concrete problems of sickness, disease and death. For a summary of the literature and theory, see Alter 1999. However, with respect to the whole question of how Âyurveda defines good health as ontologically problematic, particularly - but not exclusively -in the chapter dealing with Rasayana therapy, there are important links between yoga theory and the idea of pharmaceutically induced immortality. Given that the Carakasamhita 
focus on a key point here: hatha yoga is profoundly materialist with respect to how the body is understood and experienced, and yet there is no sense in which this materialism is mundane or commonplace.

One of the terms that Eliade uses to explain the nature of yogic perfection is immortality. The Sanskrit term that is rendered as immortality is amritatua which derives from amrita. As Georg Feuerstein puts it, in the context of hatha yoga amrita refers to 'the nectar of immortality that trickles down from an esoteric center in the head'. ${ }^{32}$ According to the Hathyogapradipika, 'the whole body should be flooded with this ambrosia, which produces a superior body endowed with enormous strength and vigor and is free from disease' ${ }^{33}$ With reference to the material body, the ideal of immortality is linked to two important ideas - change to a state of changelessness, and power over death. In many respects the best way to think about this is as a kind of embodied attempt to experience creation in reverse - since creation itself is an ongoing process - and as a 'reconquest of the completeness that precedes all creation'. ${ }^{34}$ This completeness, is, in some sense, a perfect state of transcendence; the embodiment of pure purusha (transcendental self) as the cosmic Self apart from prakriti (elemental nature). ${ }^{35}$ Since this transcendence is an embodied experience, the body-itself a conglomerate of prakritic elements - is perfected through the practice of yoga. However, this state of embodied perfection manifests itself in ways that are not in the least bit mundane or even physiological in any common sense sense, since prakriti extends, at its deepest 'alinga' (formless) level, into the domain of the supernatural. How that which is defined as 'nature' can also be defined as 'supernatural' is made possible by virtue of the fact that the prakritic state in which there is perfect equipoise between all three guna

took contemporary form at approximately the same time as important early tantric texts were being composed - ninth to tenth century CE-which was also a time when alchemy was emerging in practice, it would be important to re-examine the possible links between Âyurveda, yoga and alchemy to get a better understanding of the early connection between medicine and magical transubstantiation.

${ }^{32}$ Feuerstein 1990, p. 21.

${ }_{33}$ Hathayogapradipika IV: 53.

${ }^{34}$ Eliade 1990, p. 271.

35 Purusha and prakriti are cosmic principles that derive from Samkhya metaphysics. Purusha is the principle of transcendent, universal cosmic consciousness often referred to as 'the Self' and prakriti is the latent energy and material base of all things in the universe. 
(psychosomatic strands) is beyond normal human perception. What this does is allow for an understanding of magic as embodied supernatural nature.

Any consideration of the pre-twentieth-century hatha yoga literature-and also the Yoga Sutra, including all of Book III-must focus directly on the question of embodied siddhi powers. The word siddhi means attainment or success, but in the context of yoga it signifies perfection and means the embodiment of perfection. In the Yoga Sutra, siddhi powers are acquired through the practice of the three 'higher' samyama stages of yoga and include the power to become invisible, to be in two places at the same time, to change shape and size, to levitate and fly through the air, and to enter another person's body, among many other things. Although miraculous, it is of great importance to understand such things as invisibility and levitation in terms of what might be called yogic natural science. Eliade quotes Vacaspatimisra, one of the early redactors of the Yoga Sutra, as follows:

The body is formed of the five essences (tattva). It becomes an object perceptible to the eye by virtue of the fact that it possesses a form (rupa, which also means color). It is through this rupa that the body and its form become objects of perception. When the yogic practices samyama on the form of the body, he destroys the perceptibility of the color (rupa) that is the cause of perception of the body. Thus, when the possibility of perception is suspended, the yogin becomes invisible. The light engendered in the eye of another person no longer comes into contact with the body that has disappeared. In other words, the yogin's body is not an object of knowledge for any other man. The yogin disappears when he wishes not to be seen by anyone. ${ }^{36}$

In hatha yoga the 'natural' nature of magic is even more clearly indicated, and more important to embodied practice than in the roga Sutra. ${ }^{37}$ Most significantly it is achieved by means of asana and

${ }^{36}$ Eliade 1990, p. 87.

37 There is a great deal more that could be said about the place of magic in the Yoga Sutra. For various reasons the aphorisms have come to be viewed, incorrectly, as synonymous with Raja $Y_{o g a}$, which is infused with ideas about the occult but elides the issue of magic. In any case, as Elizabeth De Michelis has pointed out, there is a great deal of confusion about what the term Raja Yoga signifiesboth unto itself and in relation to the Yoga Sutra-and in large part this confusion stems from inaccurate Theosophist amalgamations and Vivekananda's uncritical and 
pranayama. Although a number of asanas are said to impart 'miraculous powers', by far the most common references in the classical hatha yoga texts are to the way in which asana destroy death and decay. Clearly there are many references to the healing and curative power of asanas, but these 'mundane' powers are always framed as siddhis. For example, the Hathyogapradipika describes and then explains the power associated with mayurasana (the peacock pose).

This asana destroys all diseases, removes abdominal disorders, and also [those disorders] arising from irregularities of phlegm, bile and wind. [It enables the practitioner to] digest unwholesome food taken in excess, increases appetite, and destroys the most deadly poison. ${ }^{38}$

Although asana and pranayama have come to be regarded as the core elements of hatha yoga-built on the foundation of the first and second 'limbs' of the eightfold yogic path, yama (restraint; moral observance) and niyama (restraint; purification practices) - it is important to remember that hatha yoga texts place a great deal of emphasis on preliminary purifications or shat-karma, including those styled dhauti, basti, neti, nauli, trataka and kapal bhati. Often these techniques of purification are not even included in the practice of modern yoga, but when they are it is primarily for their 'hygienic', 'tonic' and therapeutic qualities. ${ }^{39}$ However, as becomes clear in the context of alchemy, the purification of the body through these techniques entails a kind of supernatural transubstantiation of the gross body into a body of gold. In the Gherandasamhita, for example, vastara dhauti, a technique of swallowing a strip of cotton cloth and then drawing it out, is said to 'purify the body, destroy all diseases and increase the gastric fire'; varisara dhauti, a technique of swallowing water and forcefully expelling it from the rectum) gives one a 'luminous, shining

problematic linking of his seminal book, Raja Yoga 1896, directly to the aphorisms of De Michelis 2004, pp. 178-80.

${ }^{38}$ Hathayogapradipika I: 33.

${ }^{39}$ Based on field research in India and a review of the extensive popular literature there, as compared with a very unsystematic and purely subjective evaluation of the pattern in the USA, my sense is that kriya procedures, i.e. purification techniques, are included in the practice of therapeutic yoga in India, whereas asana and pranayama are practised without much concern for internal and external 'purification' in the USA, at least in similar contexts where yoga is being used to treat chronic disorders and most certainly in situations where it is being practised as a fitness regimen. 
body... He who practices it with ease, purifies his filthy body and turns it into a shining one'. ${ }^{40}$ Bahiskrita dhauti is described as follows:

By Kakachanchu or crow-billed mudra fill the stomach with air, hold it there for one and half hours and then force it down towards the intestines. This dhauti must be kept a great secret, and must not be revealed to anybody. Then, standing in navel-deep water, draw out the saktinadi (long intestines), clean the nadi carefully by hand until all of the filth is washed away, and then draw it back into the abdomen. This process should be kept secret. It is not easily done even by the gods. Simply by this dhauti one gets deva-deha, a god-like body. ${ }^{41}$

Purification of the body in the context of these kriya techniques helps to better understand a specific, and perhaps most significant, aspect of pranayama - the purification of nadis (subtle energy conduits), as the purification of nadis imparts phenomenal powers. Delineating the power of pranayama, the Gherandasamhita points out that

the power of levitation is attained by pranayama; diseases are cured by pranayama; spiritual energy is awakened by pranayama; by pranayama one becomes clairvoyant, and the mind becomes full of bliss...2

According to both the Gherandasamhita (1650 CE) and the Shivasamhita $(1750 \mathrm{CE})$ the practice of pranayama produces supernatural powers that are delineated in a comprehensive list of 81 siddhis techniques. ${ }^{43}$ These siddhis are directly linked to the purification of all nadis in general, and the three primary ones - ida, pingla, sushumna - in particular. ${ }^{44}$ Very significantly, the process of purification is described as a gradual process wherein the adept needs less and less sleep, needs to eat less and less, excretes less and less, urinates less and less and in general terms 'shuts down' the gross body and immobilises its natural functions. However, any sense in which the term 'immobilise' might be regarded as problematic, compromising, limiting or tinged with any other pejorative connotations, is completely wrong,

40 Gherandasamhita I: 16, 18-19.

41 Gherandasamhita I: 23-24.

${ }^{42}$ Gherandasamhita V: 57.

${ }^{43}$ Gherandasamhita V: 1, 2; Shivasamhita III: 51, 52.

${ }^{44}$ Hathayogapradipika II: 4-9, 11, 20, 40; Shivasamhita III: 26. 
for yogic immobilisation reflects perfection and absolute purity. As described in the Yoga-Bija: ${ }^{45}$

The [yogin's] body is like the ether, even purer than the ether. His body is more subtle than the subtlest, coarser than any coarse [object], more insensitive [to pain, etc.] than the [most] insensitive. ${ }^{46}$

Hatha yoga does to the body of an adept, what alchemists do to base metals. ${ }^{47}$ Although it is possible to think of this purely in symbolic terms, it is important to keep in mind the fundamentally materialist orientation of both yoga and alchemy. It does not make any more sense to say that base metals become like gold, than it does to say that the body of an adept becomes god-like. In both cases practice must be understood literally and completely rather than figuratively and metaphorically, otherwise doing yoga or doing alchemy does not make logical sense. The very fact that yoga and alchemy both require practice - doing things with a purpose - means that we can focus on logic and phenomenological experience and ignore the question of whether or not they are rational in some abstract sense.

Space does not permit a complete excursion into the domain of alchemy. Eliade felt that an excursion all the way to Egypt and China was necessary to explain yoga, although alchemy had an important influence on āyurveda. ${ }^{48}$ The important link between yoga and alchemy is mercury, and the way in which mercury fires, purifies and 'fixes' - in the sense of stabilizing - base metals, thereby transforming them into gold. Siddha medicine is, at least in large part, based on the idea that mercury can restore youth, and the chapter on Rasayana rejuvenation therapy in ayurveda is based on a regimen of radical decay and deterioration induced by the consumption of soma (elixir of immortality). This is followed by a process of gradual rebirth, rejuvenation, and the production of an immortal, youthful body.

Situating the hatha yoga literature within the literature on alchemy,

${ }^{45}$ The Yoga Bija is a short treatise said to be composed by Gorakshanath which is very similar to the Moga Shikha Upanishad. Its primary concern is with the resolution of opposites, both conceptual and material, into nonduality. See Feuerstein 2001, p. 421.

${ }_{46}$ Yoga Bija 53ff., Georg Feuerstein's translation 1990, p. 134.

${ }^{47}$ Eliade [1958] 1990; Rosu 1982, 1986; White 1996.

${ }^{48}$ Eliade 1990, pp. 274-92. 
siddha medicine, and āyurveda, it becomes quite clear that there is a direct correspondence between mercury and soma on the one hand and semen on the other. This follows from cosmic symbology. But, again, what is important here is not mystical analogy but the materialist connection that is effected between these substances by virtue of yoga, alchemy and medicine all being applied, empirically grounded systems of practice. As David White puts it:

It is here, at the level of the replenishment and maintenance of vital fluids, and most particularly the vital fluid that is semen, that the disciplines of Āyurveda and hatha yoga intersect: the same semen that the physician identifies with male virility and vitality is the sine qua non of yogic practice: semen is the raw material and fuel of every psychochemical transformation the yogin, alchemist and tantric practitioner undergoes, transformations through which a new superhuman and immortal body is 'conceived' out of the husk of the mortal, conditioned, biological body. ${ }^{49}$

Tantric literature makes the most direct and unambiguous connection between semen and elixirs of immortality in this context. Let me quote Eliade who masterfully weaves together a series of points that have become notorious by virtue of the Orientalist 'erotics' they bespeak. For this reason and others they are directly relevant here.

To hasten the ascent of the kundalini, some tantric schools combined corporal positions (mudra) with sexual practices. The underlying idea was the necessity of achieving simultaneous 'immobility' of breath, thought and semen. The Goraksa Samhita (61-71) states that during the khecharimudra the bindu (= sperm) 'does not fall' even if one is embraced by a woman. And, 'while the bindu remains in the body there is no fear of Death. Even if the bindu has reached the fire (is ejaculated) it straightaway returns, arrested ... by the yonimudra'. The Hathayogapradipika (III, 82) recommends the vajrolimudra for the same purpose. Milk and an 'obedient woman' are required. The yogin 'should draw back up again with the medhra (the bindu discharged in maithuna)', and the same act of reabsorption must be performed by the woman.... All of these texts insist upon the interdependence between breath, psychomental experience, and the semen virile. So long as the air (breath) moves, bindu moves; (and) it becomes stationary (when the air) ceases to move. The Yogi should, therefore, control the air and obtain immovability. ${ }^{50}$

${ }^{49}$ White 1996, p. 27. 
Granted, there is absolutely no reason to assume that it is necessary to practise vajrolimudra (reversing the flow of semen) in order to practise yoga, or to say that unless one perfects the practice of vajrolimu$d r a$ all else is for nought. My point is simply that, beyond the specifics of particular techniques such as vajrolimudra, yoga was constructed with reference to an internal logic wherein semen, the retention of semen and, ultimately, the internal self-contained ejaculation of semen-represented iconographically as the serpent power raising up the sushumna nadi - transforms the gross body into a body of golden, immortal, perfect permanence.

\section{Medicalised magic: the invention of modern scientific yoga}

Before turning to a discussion of Swami Kuvalyananda's and Shri Yogendra's struggle with magic, alchemy and sex, let me briefly point out what probably does not need to be pointed out. More than likely there are several thousand popular, technical and scientific works available that advocate the practice of yoga, in one form or another, to either cure or treat a whole spectrum of diseases or alleviate stress and promote overall health and fitness. The vast majority of these books seek to make sense of yoga's health value in terms of rational, objective scientific principles. That is, they seek to make sense of yoga with reference to a distinctly modern understanding of health and disease, and a modern prioritisation of the direct and reciprocal interlinking of health and disease. It is possible to think of health without framing it in terms of disease, but the development of medical knowledge and the fact that disease causes discomfort and deathwhereas good health is not necessarily something you need to think or worry about-makes it very difficult to extract a 'pure positive' from a field defined by the negative case. However, in trying to interpret the long stretch of yoga's history - as well as modern medicalisation - it is worth thinking about the body without thinking about poor health as the primary problem. With the aim of perfection, and the technology of perfection, life is far more problematic than death.

${ }^{50}$ Eliade 1990, pp. 248-9. Quotations are from Brigg's translation of the Goraksa Samhita (1938, pp. 298, 333, 334, 302). 
Yoga in one permutation or another can, and is, used effectively in the treatment of diabetes, asthma, depression, hypertension, and drug de-addiction, among a host of other medical problems. ${ }^{51}$ It is also used effectively as a kind of preventive, health promoting therapy. Why and how yoga is effective as a health promoting therapy is still very much an open question, but it is a question that is almost always exclusively framed in terms of a modern understanding of the body, and of the various ways in which the body, mind and soul are configured with reference to modern science on the one hand and modern spirituality, broadly defined, on the other. The reason for this is that there is no history of yoga as medicine (if we define medicine as the apparatus for treating disease) that extends back more than 80 years. In this context claims made in the hatha yoga literature from the fourteenth through the eighteenth century about embodied immortality and the magical conquest of death and disease, are at once powerful articulations of yoga's possible medical efficacy. Yet they are also anathema with regard to a search for the modern, scientific legitimacy.

As Elizabeth de Michelis has argued, modern yoga emerged as a transnational phenomenon of the late colonial period. It was a direct consequence of Swami Vivekananda's speech given at the World Parliament of Religions in Chicago, 1893, and his subsequent travels and lectures throughout the United States. ${ }^{52}$ Vivekananda's 'paradigm shifting' Raja Yoga is one of the earliest and most explicit attempts to define yoga with reference to modern ideas about science and religiosity. ${ }^{53}$ Clearly Vivekananda's teachings have had a

51 See, for example, Rama 1980; Rama and Ajaya 1976; Kuvalyananda 1963. References to texts is here a relatively poor device for demonstrating the efficacy of yoga therapy, since anyone is able to claim anything by publishing on the subject. However, based on field research in India, primarily with the members of the Bharatiya Yog Sansthan (See Alter 1997, 2000), but also at various clinics, research institutes and nature cure hospitals where yoga is used as a primary modality of treatment, such as the Bapu Nature Cure Hospital and Yoga Ashram, there is no question that yoga-defined in various explicitly modern ways in the context of applied treatment--is being used effectively. The argument being made in this paper is that the 'effectiveness' of yoga therapy emerges out of a very complex set of meanings that have themselves emerged out of a history of practice wherein there is a high degree of ambivalence about the question of what yoga is and what it should be.

${ }_{52}$ De Michelis 2004.

${ }^{53}$ Vivekananda 1976. 
profound impact on what has come to be called neo-Hinduism. However, as De Michelis points out, Raja Yoga contains numerous references and allusions to anatomy and physiology. These references should be understood, at least in part, by appreciating the extent to which Vivekananda was impressed, and perhaps influenced by, the late nineteenth-century health reform movement in the United States of America. ${ }^{54}$ In other words, although primarily concerned with spirituality, Vivekananda seems to have launched yoga in the direction of health and medicine.

Born as Narendranath Datta in 1863, Vivekananda was educated at the Mission College of Calcutta before becoming the disciple of Shri Ramakrishna. He renounced the world in 1886 and soon thereafter established the Ramakrishna Order that has developed into the world-renown Ramakrishna Mission. At about the time Datta was born, and from a similar background of mission school education, a young boy who was to become Parmahansa Madhavdasji was training for the civil service exam in Calcutta. After passing the exam and serving for several years in the judicial branch, he became profoundly disillusioned with government service - and all worldly workand renounced the world to go in search of higher knowledge. Like Vivekananda he was to have a profound influence on the history of modern yoga. ${ }^{55}$

As the intensely competitive disciples of Parmahansa Madhavdasji, who established an ashram near Bombay in the early years of the last century, J.G. Gune and Manibhai Haribhai Desai confronted the knotty problem of modernising yoga head on. They tried to reconcile magic, alchemy and secret, esoteric knowledge with the modern priorities of health, the treatment of disease, and the dissemination of knowledge about these issues to the public at large. Both men claimed to have developed and applied the direct teaching of their guru who, they said, had learned yoga while wandering in the

${ }^{54}$ See Alter 2000 and 2004 for a discussion of the way in which 'things Indian' were influenced by this health reform movement as well as the way in which 'things Indian' were incorporated into it, quite independent of Vivekananda.

${ }^{55}$ I would like to thank Peter Schreiner for reminding me, and impressing upon me, the importance of the similarity between Vivekananda's and Madhavdasji's respective life trajectories. Much more work needs to be done on the history of world renunciation in late nineteenth-century colonial India, as world renunciation is linked to colonialism and discourses of modernisation. 
Himalayas. Aside from the question of what Madhavdasji taught each of them, what is most significant is that Desai and Gune were probably the first, and certainly the most influential, teachers of a kind of yoga that is described as simple, straightforward, safe and accessible to anyone willing to engage in practice. Moreover, they were certainly the first and most influential exponents of yoga as a kind of preventive physical fitness training for the public at large, and the earliest advocates for using yoga techniques for the treatment of diseases.

Gune established an institution called Kaivalyadhama explicitly for the scientific study of yoga, and many of the first clinical tests and experiments on asana and pranayama were conducted there in the 1920s. ${ }^{56}$ After travelling to the United States where he established the Yoga Institute in New York, Desai returned to Bombay where he had first started to teach yoga and re-established the Yoga Institute as a clinic, teaching institute and research centre. ${ }^{57}$ Beginning around 1920 and gaining momentum in the decades that followed, the Yoga Institute (1918) and Kaivalyadhama (1921) have produced a vast network of teachers trained in the practice of modern yoga. Both have played a central role in the Government of India's support for the development of yoga as an indigenous system of physical education and as an indigenous system of alternative medicine. These institutions have also generated a voluminous literature over the course of the past 70 years. ${ }^{58}$ The combined influence of this literature and the exponential growth of teachers teaching other teachers has, in

${ }^{56}$ A published bibliography with abstracts (Bhole 1985) indicates that approximately 200 different experiments were conducted between 1924 and 1984, a figure that does not include numerous descriptive reports of yoga procedures and comparative commentaries on the relationship between contemporary practice and accounts given in the classical texts.

${ }^{57}$ For a more detailed account of Yogendra's life and career see Alter (unpublished manuscript. Email: jsalter+@pitt.edu for publication details). Most of the material here is taken from a biography written by Rodrigues 1982, published by The Yoga Institute.

${ }^{58}$ Each institution has its own publishing unit and has produced numerous books. Significantly both institutions have published journals almost continuously since the 1920s. Yoga Mimamsa provides very important insight into the development of yoga as a science in the context of Indian modernity. Yoga and Total Health is the organ of The Yoga Institute and, among other things, catalogues the history of yoga teacher training in India and the development of Shri Yogendra's work over the years. 
effect, played a very significant role in making yoga what it is today. Clearly there are other important institutions and teachers - I need only mention the obvious names of Swami Sivananda, B.K.S. Iyengar, Swami Satyanada Saraswati, Swami Vishnudevananda and Swami Gitananda-but they all emerged after Desai and Gune redefined and revolutionised the field.

While it is possible that modern yoga was reinvented several times independently by different people with no contact with or knowledge about one another, it seems quite clear that Desai and Guneseparately and in intense competition with one another - established the literary genre of the self-help yoga manual, routinised the clinical testing of asana and pranayama to measure physiological effects and medical efficacy, and formalised graded yoga courses and teacher training certificate programmes. Although B.K.S. Iyengar has probably played a more direct role in defining a specific style of modern yoga, and is the most famous practitioner of the art, and Swami Sivananda is equally well known, Desai and Gune have, arguably, played a much more influential role by virtue of their concern with simplification and secularised popularisation. Whereas throughout the 1950s, 1960s and 1970s, Iyengar was, without question, the greatest adept at asana and pranayama performance (and perhaps other branches as well) and Sivananda famously linked together spirituality with yogic health and hygiene to produce an embodied experience of the Divine Life (and trained a number of world-renown disciples who have gone on to establish yoga schools and ashrams), Desai and Gune were intent on integrating hatha yoga into school curricula and transforming it into a secularised form of public health. To the extent that most of the several thousand books now available draw implicitly, and sometimes explicitly (but not always with proper citations) on the early work of these two men, they succeeded admirably.

Although styling themselves unambiguously according to the worldly practice of a kind of yoga that was secularised and rationalised on scientific terms, early in their careers Desai and Gune defined themselves, paradoxically, as svamis. That is, they cast themselves in the role of 'spiritual masters of themselves', in the yogic sense of having realised the Self, and having supernatural power as a result of this realisation. Desai became Shri Yogendra-after briefly referring to himself as Swami Yogananda - and Gune became Swami Kuvalyananda. The name of the scientific institute that Kuvalyananda 
founded refers to the principle of kaivalya which means 'aloneness' as well as 'the Self's innate capacity for unbroken apperception of the contents of consciousness ... [and the] involution of the primary constituents of Nature ${ }^{59}$ Although disavowing the possibility that there was anything magical about the way in which he could manipulate the nature of his body, this is the description given of a demonstration Shri Yogendra put on for New York physicians in an apartment on Riverside Drive around 1918.

The demonstration included the process of neti, dhauti, basti, a few complicated asanas, voluntary breathing through one lung at a time, [and] the control of body heat at will. The discharge of electric light in a dark room from the fingers, its transmission beyond walls, its introduction into another body and its voluntary control by switching of the thumbs, were all demonstrated. ${ }^{60}$

There is a range of evidence that Yogendra and Kuvalyananda not only understood and recognised but on some level also sought to embody yoga in terms other than the terms in which they sought to modernise it. Photographs of both men reveal that, beneath their lab coats, they also affected the appearance of yogis with long hair and, in Yogendra's case, a long flowing beard.

In their earliest, most important and most influential writings Gune and Desai claim that they learned yoga directly from Madhavdasji. Very little is said about exactly what Madhavdasji taught each of them, but there is a clear sense that he was regarded as having magical power, and that he had about him the aura of one who embodied enlightenment. He was, in other words, regarded by both Desai and Gune as a j̈wanmukta. They recount instances in which Madhavdasji performed miraculous feats - curing a rickshaw-puller after he was bitten by a snake, entering into people's thoughts, being able to vanish from a photographic image and to produce endless pieces of candy to distribute among children when appearing in public. There are also passing and cursory references to the way in which Madhavdasji would sometimes advise sick people to perform yoga in order to cure themselves. But far more common are references to the way

\footnotetext{
${ }^{59}$ Feuerstein 1990, p. 164.
}

${ }^{60}$ Rodrigues 1982, p. 96. 
in which he cured people by means of his own supernatural power, such as the man who was bitten by a snake from whose leg the sage drew poison. There is a whole world of differences between these two modalities of treatment.

In their early books and essays, Gune and Desai make little or no reference to the medieval hatha yoga literature. This is not surprising since they claim to be modernising techniques learned directly from Madhavdasji. However, in many ways it is the spectre of this literature, or key elements of it, that seem to haunt their efforts, since both men speak out forcefully and emphatically against socalled secret arcane mystical knowledge, all aspects of the occult, 'irrationality', and what are referred to as the gross perversions of 'black magic'. Writing of the way in which yogins 'zealously guarded their treasure chest of knowledge', Desai points out that:

While such traditions of yoga education served the purpose of cultural purity ... it also gave rise to a species of mysticism and inertia which gradually resulted in confusion with regard to its rightful place in the process of civilization and for the progress of society. Unscrupulous followers are mainly responsible for this debacle.

The ignorant and misinformed have come to believe that [yoga] is some form of white or black magic, obscure sorcery, pseudo-supernatural trickery, physical and mental mortification or orgies of secret ritualism through which, in some unaccountable manner, miraculous feats are performed. ${ }^{61}$

On one level it is difficult to reconcile Desai's unquestioning belief in, and obvious respect for, Madhavdasji's 'miraculous feats' - as well as his own performance in New York - with his characterisation of the debacle of debauched yoga, and his profound doubt about magic, sorcery, trickery and other such things. In part, at least, when speaking of Madhavdasji Desai as a respectful disciple, and when he writes about the practice of yoga, he does so as an authoritative teachera modern Guru. Beyond this, however, both Desai and Gune were very self-consciously working against a well-established Orientalist preoccupation with the occult, as this preoccupation was reflected in some popular books published around the turn of the century and institutionalised in a number of societies and organisations, most

61 Yogendra 1991, pp. 18-19. 
notably The Theosophical Society. ${ }^{62}$ Both men walked a very fine, and not always consistently straight, line between involvement with and rejection of some of these organisations.

Nevertheless, in general it was the occultist Orientalists who Gune and Desai regarded as being not only 'ignorant and misinformed' but also unscrupulous in their determined search to find, in India, everything strange, exotic and other worldly, and then to claim that what they had found was so arcane that it could hardly be understood by anyone. Beyond this, it is important to note that hatha yoga has a long history of being regarded, from the vantage point of orthodox mainstream scepticism, as 'the product of cultural decline'. Perhaps the most outspoken critic of hatha yoga was Vijnana Bhikshu, a sixteenth-century scholar who looked down on embodied magic from the vantage point of theistic Vedanta. In other words, in developing and maintaining their critique of the occultists, Desai and Gune could position themselves in the good company of a long line of classical Indian scholars.

In light of this, however, the hatha yoga literature, as well as the lesser known histories of practice, one strand of which lead up to Madhavdasji's embodied transcendental experiences in mountains north of Assam, presents a serious and very complex problem on a number of fronts. Clearly those interested in the occult were, and continue to be, very interested in the hatha yoga literature, as well as the literature on alchemy and tantric practice. But in dismissing the occultists as ignorant and misinformed, and in claiming that asana and pranayama were simple, safe and natural forms of 'physical culture', Desai and Gune were left with a problem that simply could

${ }^{62}$ See Bosc 1893; De Laurence 1909; Dvivedi 1885; T.C.R. Iyengar 1908; Jacolliot 1885. See Besant 1913 and Blavatsky 1931, concerning the Theosophical Society. For an overview of this literature in the context of Shri Yogendra's reaction to it, see Alter (unpublished manuscript). Not surprisingly there was a surge of interest in yoga as an 'occult science' in the decades immediately following Vivekananda's travels in the USA. Of particular note are books by William Walker Atkinson written under the name of Yogi Ramacharaka (1904, 1905a, 1905b, 1909, 1934), Arthur Ewing's doctoral dissertation on breath and Hindu 'psycho-physics' (1901), Sarkar's book on 'the Hindu system of self-culture' (1902), and Yogi Wassan's popular account of nadi and chakra physiology (1921) and his 'revelation' of the secret knowledge of health and prana (1922). Anderson published almost all of his books out of the Yogi Publication Society of Chicago, and it would be important to study the connection between this society, Vivekananda's tour and the health reform movement that was, at that time, quite pervasive throughout the mid-western states of the USA. 
not and still can not be resolved: the very same asana and pranayama techniques that were taught by Desai and Gune [through the medium of books like Breathing Methods, Yoga Personal Hygiene and Asana Simplifed], and the same asana and pranayama that are now described in numerous publications ranging from B.K.S. Iyengar's brilliant and beautiful Light on Yoga to the coarse absurdity of Yoga for Dummies, are described in the Hathayogapradipika (1350 CE) as secret techniques that when performed properly enable one to fly, change shape and size, enter another person's body and ultimately become immortal. ${ }^{63}$

One could argue endlessly that one perspective is right and the other wrong; that yoga is either inherently magical, mystical and esoteric, or natural, healthy and curative; that it can be explained by a science other than itself, or that it cannot. Speaking strictly as an academic - and as a practitioner of vijnana (intellectual knowledge) rather than jnana (wisdom) yoga and malla vidya (knowledge of wrestling) rather hatha vidya (knowledge of hatha [yoga]) - yoga makes much better sense to me in terms of what is written in the medieval literature than in what appears in modern texts, either popular or scientific. Regardless, the simple point I wish to make here is that, for better or worse, contemporary yoga emerges out of the modern juxtaposition of the natural and the supernatural conceived of as categorically different realms of experience. That is, it emerges out of the always being asked and never finally answered questions that mirror each other: where is the proof that prana flows through the sushumna; where is the evidence that yogis can live forever by stopping their breath and the flow of their semen? Conversely, where is the proof that they cannot? It is the power of these unanswerable questions that makes yoga powerful.

Apart from the fact that yoga does help to alleviate stress, relieve the symptoms of asthma, diabetes and many other ailments, ${ }^{64}$ and in general promotes a healthy life style, its popularity and significance as a modern cultural system can and must be explained by the way in which, no matter how basic, crudely described or radically modified (using props, bouncing balls, rhythmic movements and mass drill

63 Yogendra 1936, 1940; Iyengar 1976, 1993; Feuerstein and Payne 2000.

${ }^{64}$ See Monro et al. 1989, for one of the most comprehensive and carefully compiled bibliographies detailing the modern history of scientific research on the efficacy of yoga therapy and the effect of yoga practice on physiology and anatomy. 
commands, as well as rather expensive costumes and upscale rubberised mats), every asana evokes the possibility of embodied immortality. Historically speaking, immortality is much more central to what yoga is all about, and more firmly grounded in reality, as reality is defined by context (in this case alchemy, tantra and an understanding of nature based on Samkhya philosophy), than the somewhat magical transformation of siddhis into medicine over the course of a very short period of time. ${ }^{65}$

But in this day and age science not only defines the rules but determines what game is being played. The game today is healthholistic and preventive, or not so holistic and remedial-and the rules are that no one has a perfect body, and that you cannot live forever. As a result, those who practise yoga are left, simply, with the task of endlessly redacting, elaborating, and devising techniques of practice to achieve, whatever Svatvarama, the author of the Hathyogapradipika meant when he said that the practice of asana and pranayam conquers death, decay and disease. We should also not forget that at the end of his treatise Svatvarama also said:

As long as prana does not flow in the middle channel, and bindu [semen] does not become firm by the control of the movements of prana; as long as the mind in contemplation does not assume the form of Brahma without any effort, so long all the talk of knowledge and wisdom is merely the nonsensical babbling of mad men. ${ }^{66}$

Thus one is left with a paradox in the relationship between ends and means. Without having experienced enlightenment, everything said about yoga must be understood as nonsense. And yet the techniques of yoga that are designed to produce perfection - and about which much has been said in the context of modern medicalisation-are what lead to enlightenment.

${ }^{65}$ The use of the term 'magical' here is not merely a rhetorical device, for history itself involves the transformation of nature and truth, and it was a spark of geniusMadhavdasji's, Kuvalyananda's or Yogendra's - to effect such a transformation by turning the base metal of embodied alchemy into the lucrative gold of modern medical yoga.

${ }_{66}$ Hathayogapradipika IV: 113. 


\section{References}

Alter, Joseph S. 1994, 'Celibacy, Sexuality and the Transformation of Gender in Nationalism', Joumal of Asian Studies, 53: 45-66.

— 1997, 'A Therapy to Live By: Public Health, the Self and Nationalism in the Practice of a North Indian Yoga Society', Medical Anthropology, 17: 309-35.

- 1999, 'Heaps of Health, Metaphysical Fitness: Âyurveda and the Ontology of Good Health in Medical Anthropology', Current Anthropology, 40: s43-s66.

- 2000, Gandhi's Body: Sex, Diet and the Politics of Nationalism, Philadelphia: University of Pennsylvania Press.

- 2004, Yoga in Modern India: The Body Between Science and Philosophy, Princeton: Princeton University Press.

- manuscript, 'Shri Yogendra and the Yoga Self-Help Literature: Telling (But Not Really Telling) the Guru's Secret'.

Ananada Samuccaya n.d., Ujjain: Scindia Oriental Institute.

Behanan, Kovoor Thomas 1937, Yoga; A Scientific Evaluation, New York: The Macmillan Company.

Bernard, Theos. 1944, Hatha Yoga: The Report of a Personal Experience, New York: Columbia University Press.

Besant, Annie Wood 1913, Evolution and Occultism, London: Theosophical Publishing Society.

Bhole, M.V. 1985, Abstracts and Bibliography of Articles on Yoga From Kaivalyadhama, Lonavala: Kaivalyadhama S.M.Y.M. Samithi.

Blavatsky, H.P. 1931, Raja-Yoga, or Occultism, Bombay: Theosophy Company.

Bosc, Ernest 1893, Addha-Nari; Ou, L'Occultisme Dans L'Inde Antique. Védisme, Littérature Hindoue, Mythes, Religions... [Etc.], Paris: Librairie Galignani.

Brhadyogiyajnavalkyasmrti 1951, Lonavala: Kaivalyadhama S.M.Y.M.

Briggs, George W. 1938, Gorakhnath and the Kanphata Yogis, Calcutta: Y.M.C.A. Press.

Buoy, Christian 1994, Les Natha-Yogin et Les Upanisads, Paris, De Boccard: Publications des l'Institut de Civilisation Indinienne, No. 62.

Carpata Shataka.

Crooke, William 1926, Religion and Folklore of Northerm India, London: Oxford University Press.

De Laurence, Lauron William 1909, The Mystic Text Book of 'The Hindu Occult Chambers'; The Magic and Occultism of India; Hindu and Egyptian Crystal Gazing; The Hindu Magic Mirror, Chicago: De Laurence, Scott \& Company.

De Michelis, Elisabeth 2004, A History of Modern Yoga: Patanjali and Western Esotericism, London: Cassell.

Deussen, Paul 1966 [1906], The Philosophy of the Upanishads, New York: Dover.

Dvivedi, Manilal Nabhubhai 1992 [1885], Raja Yoga, or The Practical Metaphysics of the Vedanta: Being a Translation of the Vákyasudhá or Drigdrishyaviveka of Bháratitirtha, and the Aparokshánubhuti of Shri Shankaráchárya; With an Introduction, Appendix Containing the Sanskrit Text and Commentary of the Váklyasudhá, and Notes Explanatory and Critical, Delhi: Antiquarian Book House.

Eliade, Mircea 1990, Yoga: Immortality and Freedom, Princeton: Princeton University Press. (First published in French, 1954, as Le Yoga: Immortalite et Liberte, Paris: Librarie Payot).

Ewing, Arthur 1901, 'The Hindu Conception of the Functions of Breath: A Study in Early Hindu Psychophysics', PhD Dissertation, The Johns Hopkins University.

Farquhar, J.N. 1925, 'The Fighting Ascetics of India', Bulletin of the Fohn Rylands Library, 9: 431-52.

Faure, Bernard 1998, The Red Thread: Buddhist Approaches to Sexuality, Princeton: Princeton University Press. 
Feuerstein, Georg 1989, roga: The Technology of Ecstasy, Los Angeles: J.P. Tarcher.

- 1990, Encyclopedic Dictionary of Yoga, London: Unwin Paperbacks.

2001, The Yoga Tradition: Its History, Literature Philosophy and Practice, Prescott, AZ: Hohm.

Feuerstein, Georg and Payne, Larry 2001, Yoga for Dummies, Foster City, CA: IDG Books Worldwide.

Filliozat, Jean 1949, Magie et Medecine, Paris: Presses Universitaires de France.

1964, The Classical Doctrine of Indian Medicine: Its Origins and Greek Parallels, Delhi: Munshiram Manoharlal.

Gheranda Samhita

Ghose, J. 1930, Sannyasi and Fakir Raiders in Bengal, Calcutta: Bengal Secretariat Book Depot.

Goraksa Samhita

Hatha Ratna Avali

Hatha Sanketa Candrika

Hathayogapradipika

Iyengar, B.K.S. 1976, Light on Yoga, New York: Schocken Books.

- 1993, Light on the Yoga-Sutras of Patanjali, London: Aquarian/Thorsons.

Iyengar, Tirumangalum Krishna Rajan 1908, The Hindu-Aryan Theory on Evolution and Involution, or, The Science of Raja-Yoga, New York: Funk and Wagnalls.

Jacolliot, Louis. 1971 [1885], Occult Science in India and Among the Ancients, With an Account of Their Mystic Initiations and the History of Spiritism, New Hyde Park: University Books.

Kawakita, Yosio, Shizu Sakai, and Yasou Otsuka 1995, The Comparison of Life-Breaths in East and West, Tokyo: Ishiyaku Euro-America.

Kuriyama, Shigehisa 2002, The Expressiveness of the Body and the Divergence of Greek and Chinese Medicine, New York: Zone.

Kuvalyananda, Swami 1963, Yoga Therapy; Its Basic Principles and Methods, New Delhi: Central Health Education Bureau, D.G.H.S., Ministry of Health, Government of India.

Larson, Gerald J. and Ram S. Bhattacharya 1987, Samkhya: A Dualist Tradition in Indian Philosophy, Vol. 4 of The Encyclopedia of Indian Philosophies, Princeton: Princeton University Press.

Larson, Gerald J. 1979, Classical Samkhya: An Interpretation of Its History and Meaning, second edition, Delhi: Motilal Banarsidass.

Lorenzen, David 1972, The Kapalikas and Kalamukhas: Two Lost Saivite Sects, New Delhi: Thomson Press.

- 1978, 'Warrior Ascetics in Indian History', Journal of the American Oriental Society, 98, January-March: 61-75.

Marriott, McKim 1990, India Through Hindu Categories, New Delhi: Sage Publications.

Meulenbeld, Gerret Jan. 1999, A History of Indian Medical Literature, Groningen: E. Forsten.

Monro, Robin, A.K. Ghosh, and Daniel Kalish 1989, Yoga Research Bibliography: Scientific Studies on Yoga and Meditation, Cambridge: Yoga Biomedical Trust.

Needham, Joseph et al. 1954-988, Science and Civilization in Ancient China, 6 Volumes, Cambridge: Cambridge University Press.

Neelam, Shrimati 1993, Sex Aur Yoga, Delhi: Sadhana Pocket Books.

Oman, John Campbell 1908, Cults, Customs and Superstitions of India, London: T. Fisher Unwin.

1973, The Mystics, Ascetics and Saints of India, Delhi: Oriental Publishers.

Padoux, Andre 1988, Tantrism, in Encyclopedia of Religions, volume 14 edited by Mircea Eliade, New York: Macmillan, 272-6.

Pinch, William R. 1996, Peasants and Monks in British India, Berkeley: University of California Press. 
Rabe, Michael D. 2000, 'Secret Yantras and Erotic Display for Hindu Temples', in Tantra in Practice, edited by David Gordon White, Princeton: Princeton University Press, 434-6.

Rama, Swami 1980, A Practical Guide to Holistic Health, Honesdale, PA: Himalayan Institute.

Rama, Swami, and Swami Ajay 1976, Emotion Without Enlightenment, Honesdale, PA: Himalayan Institute.

Ramacharaka, Yogi 1904, Hatha Yoga, Chicago: Yogi Publication Society.

— 1905a, Science of Breath; A Complete Manual of the Oriental Breathing Philosophy of Physical, Mental, Psychic and Spiritual Development, Chicago: Yogi Publication Society.

- 1905b, Advanced Course in Yogi Philosophy and Oriental Occultism, Chicago: Yogi Publication Society.

1909, The Hindu-Yogi System of Practical Water Cure, As Practiced in India and Other Oriental Countries, Chicago: The Yogi Publication Society.

- 1934, A Series of Lessons in Raja Yoga, Chicago: Chicago Yogi Publication Society.

Rele, Vasant Gangaram 1927, The Mysterious Kundalini The Physical Basis of the 'Kundali (Hatha) Yoga' According to Our Present Knowledge of Western Anatomy and Physiology, Bombay: B.B. Taraporevala.

Rodrigues, Santan 1982, Life of Shri Yogendra the Householder Yogi, Bombay: Yoga Institute.

Rosselli, John 1980, 'The Self-Image of Effetness: Physical Education and Nationalism in Nineteenth-Century Bengal', Past and Present, 86: 121-48.

Rosu, Arion 1982, 'Yoga et Alchimie', Zeitschrift Der Deutschen Morgenlandischen Gesellschaft, 132: $363-79$.

_ 1986, 'Mantra et Yantra dans la Medecine et L'Alchimie Indiennnes', Joumal Asiatique, 274, 3-4: 205-68.

Roy, A.T. 1930, Nervous System of the Ancient Hindus, Hazrathbagh.

Sanderson, Alexis 1988, 'Saivism and the Tantric Tradition', The World's Religions, edited by S. Sutherland et al., London: Routledge and Kegan Paul: 660-704.

Sarkar, Kishori Lal 1902, The Hindu System of Self-Culture of the Patanjala Yoga Shastra, Calcutta: Sarasi Lal.

Sharma, Shiv and Kailash Nath Sharma 1991, Yoga and Sex, Bombay: B.I. Publications.

Shiva Samhita

Siddha Siddhanta Paddhati

Siegel, Lee 1991, Net of Magic: Wonders and Deceptions in India, Chicago: University of Chicago Press.

Singh, Mohan 1937, Gorakhnath and Mediaeval Hindu Mysticism, Lahore.

Sivananda Sarasvati, Swami 1935a, Kundalini Yoga, Madras: P.K. Vinyagam.

- 1935b, Yoga Asanas, Madras: P.K. Vinyagam.

Sjoman, N. E. 1996, The Yoga Tradition of the Mysore Palace, Delhi: Abhinav Publications.

Taylor, Kathleen 2001, Sir John Woodroffe, Tantra, and Bengal: 'An Indian Soul in a European Body?', Richmond, England: Curzon Press.

Urban, Hugh B. 2003, Tantra: Sex, Secrecy, Politics, and Power in the Study of Religion, Berkeley: University of California Press.

Varenne, Jean 1973, Yoga and the Hindu Tradition, Delhi: Motilal Banarsidass.

Vivekananda, Swami 1976 [1896], Raja Yoga, sixteenth edition, Pithoragarh: Advaita Ashram.

Wassan, Yogi 1921, Secrets of the Yoga Philosophy, Ida, Pingla, Sukmuna, By Hindoo Superkash, Seattle: Washington Publishing Company.

1922, Secret Key to Health and Pran, Seattle: Washington Publishing Company. Whicher, Ian 1998, The Integrity of the Yoga Darsana: A Reconsideration of Classical Yoga, Albany: State University of New York Press.

Whitaker, Jarrod L. 2000, 'Divine Weapons and Tejas in the Two Indian Epics', Indo-Iranian Journal, 43: 87-113. 
White, David Gordon 1996, The Alchemical Body: Siddha Traditions in Medieval India, Chicago: University of Chicago Press.

- 2000, Tantra in Practice, Princeton: Princeton University Press.

Woodroffe, Sir John 1927, Tantra of the Great Liberation, Madras: Ganesh and Co.

- 1929, Shakti and Shakta, Madras: Ganesh and Co.

1931, The Serpent Power; Being the Shat-Chakranirupana and Paduka-Panchaka, Two Works of Laya Yoga, Madras: Ganesh and Co.

Yoga Bija

Yoga Karmika

Yoga Shastra

Yoga Shikha Unpanished (as part of the Yoga Upanishads) 1938, edited by Mahadeva Shastri, Madras: Adyar Library and Research Center.

Yoga Sutra

Yoga Vishaya

Yoga Yajnavalkya

Yogendra, Shri 1936, Breathing Methods, Bombay: The Yoga Institute.

—_ 1940, Yoga Personal Hygiene, Bombay: The Yoga Institute.

1991 [1928], Rythmic Exercises, Bombay: The Yoga Institute.

Zysk, Kenneth 1996, 'The Science of Respiration and the Doctrine of the Bodily

Winds in Ancient India', Journal of the American Oriental Society, 113: 138-213. 